\title{
PEMBANGUNAN TATA KELOLA KELAUTAN INDONESIA: PERAN HUKUM INTERNATIONAL MEMBENTUK ETIKA BISNIS KELAUTAN
}

\author{
Yohanes Hermanto Sirait, Ai Permanasari \\ Fakultas Hukum, Universitas Kristen Maranatha, Bandung \\ J1. Surya Sumantri No.65, Sukawarna, Kota Bandung, Jawa Barat 40164 \\ yohanessirait1988@gmail.com; sarilimbert@gmail.com
}

\begin{abstract}
Issues related to marine governance still need some improvement in Indonesia, where issues on determination of the maritime boundaries between Indonesia and other states are unsettled, the inadequate utilization and development of coastal areas and small islands to the large number of business activities that pollute the sea. This is due to unethical business practices and neglect of marine sustainability. This study aims to examine the development of marine governance from the perspective of international law. The development of governance can begin with the dissemination of business ethics which is an important part of marine governance. This normative juridical study, collected through literature study is analyzed using a qualitative deductive method. The results shows that international law contributes to upholding ethical standards of business and disseminating it to other states. Therefore, Indonesia needs to promote an appropriate business ethics oriented to environmental sustainability. It can begin by spreading the ethic from the international to the national level.
\end{abstract}

Key words: Business Ethic, International Law, Ocean Governance

\begin{abstract}
Abstrak
Permasalahan tata kelola laut masih butuh perbaikan di Indonesia, dimana belum beresnya penetapan batas-batas laut Indonesia dengan negara lain, belum optimalnya pemanfaatan dan pembangunan wilayah pesisir dan pulau-pulau kecil sampai pada banyaknya kegiatan bisnis yang mencemari laut. Hal ini dikarenakan praktik kegiatan bisnis yang kurang beretika dan mengabaikan kelestarian laut. Penelitian ini bertujuan untuk mengkaji bagaimana pembangunan tata kelola kelautan dapat dibangun dari perspektif Hukum Internasional. Pembangunan tata kelola dapat dimulai dengan penyebaran etika bisnis sebagai bagian penting dalam tata kelola kelautan. Penelitian yuridis normative ini dikumpulkan melalui studi kepustakaan dan dianalisis dengan metode deduktif kualitatif. Hasilnya hukum internasional berkontribusi dalam mengukuhkan standar etika bisnis dan menyebarluaskannya ke banyak negara. Untuk itu, keaktifan negara dalam mendorong etika bisnis yang berorientasi pada kelestarian lingkungan sangat dibutuhkan. Hal ini dapat dimulai dengan membudayakan etika tersebut dari level internasional ke nasional.
\end{abstract}

Kata Kunci: etika bisnis, hukum internasional, tata kelola kelautan. 


\section{Latar Belakang}

Isu mengenai laut telah menjadi perdebatan sejak berabad-abad tahun yang lalu. Banyak negara melakukan eksplorasi, penguasaan dan penjajahan melalui laut dan demi mendapatkan laut. Melalui proses yang sangat panjang, untuk pertama kalinya pada tahun 1982 disepakati suatu produk hukum yang mengatur secara global, spesifik dan eksplisit terkait dengan laut. ${ }^{1}$ Hal ini tidak lepas dari sejarah pembentukan hukum internasional itu sendiri khususunya hukum laut internasional.

Keberadaan Konvensi Hukum laut dan aturan lainnya diharapkan membawa perubahan pada tata keola laut, namun praktik selama ini menunjukkan bahwa aktivitas di laut masih kurang menghargai laut sebagai bagian dari alam. Praktek di beberapa negara terkait penangkapan ikan dengan menggunakan bahan berbahaya seperti racun dan bom, eksplorasi yang berlebihan tanpa memperhatian keberlanjutan dari sumber daya laut dan lain-lain masih jauh dari kata tertata. Belum lagi isu mengenai perubahan iklim yang juga berdampak terhadap lingkungan laut. $^{2}$

Terkait tata kelola kelautan Indonesia, instrumen hukum memang sudah ada, setidaknya Undang - Undang No. 17 Tahun 1985 tentang Pengesahan Konvensi PBB tentang Hukum Laut (United Nations Convention on the Law of the Sea UNCLOS 1982), UU Perairan, UU Kelautan, International Ship and Port Facility Security (ISPS) Code dan peraturan terkait lainnya sudah menghiasi daftar peraturan yang berhubungan dengan kelautan di Indonesia. Struktur penegak hukumnya pun telah ada, mulai dari Tentara Nasional Indonesia (TNI), Kepolisian (perairan), Badan Keamanan Laut (Bakamla), Kementerian Kelautan dan organ lainnya yang memiliki fungsi yang berhubungan dengan laut. Namun ternyata tetap persoalan tata kelola laut masih belum tuntas sampai sekarang. ${ }^{3}$

Padahal inisiasi untuk memulai tata kelola sudah ada sejak adanya Deklarasi Djuanda. Hal ini dapat dilihat dari adanya ukurannya jelas yang ditawarkan oleh Indonesia yakni laut territorial 12 mil diukur dari garis pangkal lurus yang menghubungkan titik-titik terluar dari pulau-pulau terluar yang mengelilingi kepulauan Indonesia. ${ }^{4}$ Dengan demikian, seharusnya upaya untuk mengelola laut di Indonesia lebih mudah dilakukan karena tidak perlu lagi masuk dalam perdebatan mengenai

1 Sebelum Konvensi Hukum Laut 1982 dibentuk, pada tahun 1609, Hugo Grotius mempublikasikan tulisannya yakni mare liberum (laut tidak dapat dimiliki oleh negara) yang kemudian diadopsi oleh beberapa negara lain selain Belanda. Lihat, James Harrison, Evolution of the law of the sea: developments in law-making in the wake of the 1982 Law of the Sea Convention, (Edinburgh: School of Law, University of Edinburgh, 2007) hlm. 16.

2 Dwi Aryo Tjiptohandono dan Indarwati Aminuddin, “WWF: Kondisi Kerusakan Laut Bisa Diperbaiki”, https:// www.wwf.or.id/?41882/WWF-Kondisi-Kerusakan-Laut-Bisa-Diperbaiki, diakses 22 Agustus 2019.

3 Isu tumpang tindih kewenangan dari penegak hukum di bidang kelautan juga menjadi alasan kurang efektifnya struktur hukum. Lihat, A. Kadar, "Pengelolaan Kemaritiman Menuju Indonesia sebagai Poros Maritim Dunia", Jurnal Keamanan Nasional Vol. I, No. 3, (2015): 431.

4 Tommy Hendra Purwaka, "Tinjauan Hukum Laut terhadap Wilayah Negara Kesatuan Republik Indonesia", Mimbar Hukum Vol. 26, No. 3, (Oktober 2014): 357, sebagaimana dikutip dalam R. R Churcill dan A.V. Lowe, The Law of the Sea, (Manchester: Manchester University Press, 1999), hlm. 55, 123, 124. 
batas laut Indonesia dengan negara tetangga. Jika melihat pada teori penegakan hukum Lawrence Friedman, maka yang menjadi persoalan adalah pada tataran budaya hukum.

Pelanggaran-pelanggaran yang terjadi dan berakibat buruk pada laut tentunya selain karena dipicu oleh kurangnya penegakan hukum selama ini, dapat juga dipengaruhi oleh minimnya etika dalam bisnis kelautan. Logika bisnis yang mencari keuntungan yang sebesarbesanya dengan modal sekecil-kecilnya masih kerap digunakan oleh pemangku kepentingan baik pelaku usaha, masyarakat atau pemerintah itu sendiri. Hal ini juga tentunya tidak lepas dari adanya pergesaran etika dalam berbisnis di bidang kelautan yang menganggap bahwa laut itu sangat luar biasa sehingga dampak dari perbuatan terhadap laut kerap diabaikan. Hasilnya, kegiatan yang dilakukan di laut ternyata berdampak pada lingkungan laut ke aarah yang negatif. Pergeseran etika yang berkarakter negatif tersebut pun sebenarnya sekadar akibat dari perubahan situasi yang tidak dikelola dengan baik ${ }^{5}$, dalam hal ini tata kelola kelautan yang kurang baik. Sebagai contoh dapat dilihat dalam penangkapan ikan menggunakan bahan berbahaya seperti bom dan racun yang jelas merusak lingkungan dan tidak sesuai etika.

Meskipun memang, Indonesia sebagai negara maritime terbesar di dunia memiliki tantangan terbesar juga dalam mengelola laut mengingat luas laut yang begitu besar sehingga banyak area yang perlu diawasi. Belum lagi, Indonesia juga bersebelahan dengan beberapa negara yang punya kepentingan juga terhadap laut dan sumber daya alam di dalamnya. Sehingga tidak aneh sengekta kepemilikan laut telah beberapa kali menjadikan Indonesia sebagai salah satu pihak. Kekhawatiran sengekta laut akan membawa kepada sengeketa antara negara yang melibatkan kekuatan bersenjata, untuk itu peran hukum internasional dalam membentuk etika bisnis perlu terus dilanjutkan.

Berdasarkan latar belakang diatas, penulis melakukan suatu kajian mengenai bagaimana hukum internasional dapat berkontribusi dalam membentuk etika bisnis kelautan dikaitkan dengan tata kelola kelautan (ocean governance) di Indonesia. Peran tadi dilihat dari kemampuan hukum internasional membentuk substansi etika bisnis, memperkuat institusi pembentuk etika bisnis dan mengejawantahkan aktivitas bisnis yang berbudaya dan beretika.

Penelitian ini merupakan kajian normatif yang difokuskan untuk mengkaji penerapan kaidah-kaidah atau norma-norma dalam hukum positif. ${ }^{6}$ Pendekatan yang digunakan adalah pendekatan perundang-undangan (statute approach) dan konseptual (conceptual approach) terhadap data sekunder yang terdiri dari bahan hukum primer, sekunder dan

5 Shidarta, "Dampak Pergeseran Etika dalam Kehidupan Berbangsa", dalam Komisi Yudisial, Etika dan Budaya Hukum dalam Peradilan, Cetakan Pertama, (Jakarta: SekJen Komisi Yudisial RI, 2017), hlm. 63-64.

6 Johnny Ibrahim, Teori dan Metodologi Penelitian Hukum Normatif, (Malang: Bayumedia Publishing, 2006), hlm. 295. 
tersier. ${ }^{7}$ Analisis dilakukan secara kualitatif dengan metode deduktif dari hal-hal yang bersifat umum ke hal-hal yang bersifat khusus, dari level internasional ke level nasional.

\section{Pembahasan}

\section{A. Hubungan antara Hukum Internasional, Tata Kelola Laut dengan Etika Bisnis}

Etika bisnis dari pelaku bisnis memang biasanya ditentukan oleh budaya dan standar moral dari perusahaan. Namun budaya dan standar moral perusahaan tadi juga bisa direkayasa oleh hukum suatu negara. ${ }^{8}$ Hukum yang baik tentunya dapat mendorong perilaku bisnis yang baik. Lebh lanjut, hukum suatu negara pun bisa saja dipengaruhi dari adanya kewajiban sebagai bagian dari masyarakat internasional yang diatur dalam hukum internasional. Sehingga standar di tingkat internasional dapat diadopsi untuk diimplementasikan di tingkat nasional.

Penghubung utama antara hukum internasional dengan kebijakan tata kelola adalah Konvensi Hukum Laut 1982 dan beberapa sumber hukum internasional lainnya. Sementara itu sebagaimana hukum lainnya di dalam hukum internasional juga terdapat moralitas bangsa-bangsa yang merupakan cikal bakal dalam membentuk etika termasuk etika bisnis di bidang kelautan. ${ }^{9}$ Lebih lanjut, telah dibentuk juga Organisasi Maritim Internasional dan beberapa organisasi internasional lainnya yang dapat menjadi wadal berdiskusi dan berdiplomasi antara negara. Dengan demikian hukum internasional, tata kelola laut Indonesia dan etika bisnis di bidang kelautan saling berkaitan satu dengan lainnya.

Tata kelola laut dapat dilihat dari aspek pemeliharaan atas keberlanjutan sumber daya alam laut sebagai bagian dari proses yang dibutuhkan untuk mempertahankan struktur dan fungsi ekosistem. ${ }^{10}$ Tata kelautan sendiri mengalami perubahan pendekatan dari pendekatan modern menjadi ke arah yang post modernism. Diawali pada pemanfaatan laut untuk (i) eksploitasi yang optimis; (ii) mitigasi konflik; dan (iii) mitigasi polusi sampai pada pemanfaatan laut yang dipengaruhi oleh perubahan global yakni (i) interaksi dalam perubahan global; dan (ii) interkasi dengan globalisasi itu sendiri. ${ }^{11}$

Sementara itu, secara definisi, etika bisnis dapat digambarkan sebagai suatu kajian khusus mengenai apa yang benar dan yang salah. Etika bisnis berfokus pada bagaimana standar moral

7 Ibid, hlm. 320-322.

8 Godfrey Adda, et.al, "Business Ethics and Corporate Social Responsibility for Business Success and Growth", European Journal of Business and Innovation Research, Vol.4, No.6, (December 2016): 28-29.

9 Alexander Boldizar dan Outi Korhonen, "Ethics, Morals and International Law", European Journal of International Law Vol. 10, No.2 (1999): 280.

10 D. Pyć, "Global Ocean Governance”, the International Journal on Marine Navigation and Safety of Sea Transportation Vol. 10, Number 1, (March 2016): 1.

11 Tridoyo Kusumastanto, Kebijakan Tata Kelola Kelautan Indonesia (Indonesia Ocean Governance Policy), (Bogor: Pusat Kajian Sumber Daya Pesisir dan Lautan, 2010), hlm. 21. 
beroperasi dalam suatu kebijakan, institusi dan perilaku bisnis. ${ }^{12}$ Lebih detail lagi, etika bisnis dapat dimaknai sebagai memahami apa yang benar atau salah dan dapat diterima atau tidak dapat diterima berdasarkan harapan organisasi dan masyarakat. ${ }^{13}$ Harus diakui bahwa tidak sedikit yang kesulitan membedakan antara etika dan hukum oleh karena di dalam hukum (aturan) terdapat etika. Namun demikian, keduanya tetaplah berbeda. Sebagai contoh, tidak banyak negara yang melarang percobaan obat pada hewan namun demikian jika dilihat dari etika perbuatan itu bisa jadi dilarang. ${ }^{14}$ Jadi apa yang ada dalam hukum belum tentu sesuai etika dan apa yang beretika belum tentu telah diatur dalam norma hukum.

Kebijakan, institusi dan perilaku bisnis ini jika dikaji mendalam maka akan memiliki kemiripan dengan ide pemikian Lawrance M. Friedman mengenai substansi hukum, struktur hukum dan budaya hukum. Diantara ketiganya, budaya hukum memiliki kekuatan yang lebih besar karena kekuatan sosial yang bersifat konstan berupa perilaku dan nilainilai sosial yang akan menghidupkan mesin suatu sistem hukum untuk bergerak maju atau sebaliknya berhenti. Begitu pentingnya budaya hukum, bahkan ketika substansi dan struktur hukum baik sekalipun namun tidak disertai dengan budaya hukum yang baik maka hasilnya ada tidak berjalannya sistem hukum. ${ }^{15}$

Untuk itu, penulis melihat pentingnya peran substansi hukum internasional dalam membentuk substansi etika bisnis kelautan, kemudian dilanjutkan dengan struktur hukum internasional ke dalam institusi yang membentuk etika bisnis dan terakhir budaya hukum yang melahirkan budaya beretika dalam berbisnis yang tentutnya dikhususkan dalam bidang kelautan. Sedangkan hukum internasional berperan sebagai alat rekayasa dalam membentuk etika bisnis yang terdiri dari substansi, struktur dan budaya tersebut sesuai dengan teori Roscoe Pound "law as a tool of social engineering".

Sejak awal didesain, hukum internasional tidak mengenal yang namanya trias politika. Namun demikian, ketiadaan eksekutif, legislatif dan yudikatif tidak membuat kedudukan hukum internasional melemah. ${ }^{16}$ Hukum internasional tetap mengikat bagi banyak negara karena memang negaranegara mengakui kebutuhan mereka akan hukum internasional. Hukum internasional juga dinilai sebagai suatu moralitas yang

12 L. Soproni, "Ethics in international business", Annals of the University of Oradea-International Relations and European Studies Vol. 1, (2009): 1, dapat diakses di https://nbn-resolving.org/urn:nbn:de:0168-ssoar-348177.

13 Mulyaningsih dan Tinneke Hermina, 2017, Etika Bisnis, (Bandung: Kimfa Mandiri, 2017), hlm. 1, sebagaimana dikutip dari Linda Ferrell \& O.C. Ferrell, DK Essential Managers: Ethical Business, (London DK, 2009).

14 Peter Allen Stanwick dan Sarah D Stanwick, 2015, Understanding Business Ethics, Third edition, (New YorkL SAGE Publication, 2015), hlm. 5.

15 Lihat di Kata Sambutan Ketua Komisi Yudisial dalam Komisi Yudisial, Etika dan Budaya Hukum dalam Peradilan, Cetakan Pertama, (Jakarta: SekJen Komisi Yudisial RI, 2017), hlm. v

16 Eric Myjer, The Principle of Approximate Treaty Application in Evolving principles of International Law, (Leiden: Brill-Nijhoff, 2011), hlm. 66. 
mencerminkan kewajiban moral dari satu negara ke negara lain dari suatu entitas ke entitas lain. ${ }^{17}$

Ketergantungan lingkungan yang global mengharuskan negara untuk menemukan solusidiplomatikbarudalammenyeimbangkan hak-hak yang berasal dari kedaulatan dengan kewajiban internasional dalam tata kelola sumber daya laut. ${ }^{18}$ Hal ini dikarenakan seiring terjadinya perdebatan antara mana yang menjadi lebih tinggi, apakah kedaulatan diatas kewajiban anggota masyarakat dunia atau sebaliknya maka diplomasi antar negara memiliki peran yang penting.

Kelebihan dari hukum internasional tidak hanya pada aturan yang mengikat secara global bahkan dalam beberapa kasus universal namun juga pada moralitas dan etik di dalamnya. Negara cenderung tunduk karena berharap negara lain akan tunduk seperti halnya negara tersebut. Karena memang secara etika, kurang tepat hubungan internasional dibangun tanpa sikap saling menghormati satu sama lain. Terlebih sanksi sosial lebih berperan dibandingkan sanksi hukum dalam konteks hukum internasional sebagaimana yang dinyatakan oleh John Austin. ${ }^{19}$

Peran hukum internasional dilakukan melalui peran organisasi internasional sebagai subjek hukum internasional yang terdiri dari beberapa anggota yang merupakan negaranegara yang berkepentingan di dunia. Melalui organisasi internasional, aturan dan kode etik dikenal luas dan diakui banyak negara, setidaknya oleh negara anggota. Asas-asas seperti pacta sunc servanda, kebebasan berkontrak dan good faith yang diadopsi oleh banyak negara saat ini adalah bukti kontribusi dari hukum internasional. Ibarat perusahaan periklanan, hukum internasional menyebarkan asas-asas atau prinsip-prinsip hukum umum tersebut ke banyak negara dan telah menjadi bagian dari hukum nasional suatu negara.

Untuk itu, menumbuhkan etika bisnis kelautan yang tertata di suatu negara dapat diisi oleh peran hukum internasional setidaknya sampai pada level memperluas daya berlaku dari etika bisnis tersebut. Terdapatnya pelaku lain (perusahaan (nasional atau multi nasional), organsisasi internasional dan negara lain) mendorong pembuatan etika bisnis yang dapat diterima dan diikuti banyak pihak. Etika bisnis yang diterima tentunya didasari dari moralitas hidup bersama dalam konteks regional atau global dan berdasarkan praktik-praktik terbaik (best practice) di banyak negara. Meskipun memang perlu diakui bahwa moralitas hidup bersama ini sudah ditentukan oleh karena ukurannya berbeda-beda untuk tiap negara.

Lebih lanjut, ketika kegiatan bisnis dilakukan oleh negara dengan negara baik

17 Eric A. Posner, “Do States Have a Moral Obligation to Obey International Law?", Stanford Law Review Volume 55, (2003): 1917.

18 Genevieve Quirk dan Quentin A. Hanich, “Ocean Diplomacy: The Pacific Island Countries' Campaign to the UN for an Ocean Sustainable Development Goal", Asia-pacific journal of ocean law and policy Vol. 1 No. 1 , (2016): 70.

19 Allan Munyao Mukuki, "The Normative Irrelevence of Austin's Command Theory, in International Law", MIMBAR HUKUM Vol. 28, No.3, (2018): 371. 
melalui Bilateral Investment Treaty atau tidak, praktiknya akan melibatkan subjek hukum nasional dari masing-masing negara baik itu, perorangan maupun badan hukum. Perusahaan multinasional yang merupakan subjek hukum nasional dapat dipaksa oleh negara masing-masing untuk mengikuti kode etik yang disepakati oleh negara asal maupun negara tujuan bisnis. Dengan demikian terdapat hubungan hukum tidak hanya antara negara dengan negara melainkan juga negara asal dengan perusahaan dan negara tujuan dengan perusahaan. Dengan kata lain, ketika etika bisnis sudah dimulai dari level negara maka akan mudah menurunkannya pada level perusahaan yang pada hakikatnya tunduk pada hukum negara asal dan negara tujuan bisnis. Tetapi perlu dicatat, dikatakan mudah di tataran noramti, belum tentu mudah di tataran praktik. Akan ada tantangan dan hambatan tersendiri, terlebih untuk negara berkembang seperti Indonesia yang secara finansial dan teknologi kemaritiman belum semaju negaranegara lain seperti Amerika Serikat, China, dan beberapa negara lainnya.

\section{B. Tantangan dalam Membentuk Etika Bisnis antar Negara}

Tidak dapat dipungkiri bahwa tiap negara memiliki ukuran atau standar yang berbedabeda termasuk standar apa yang etis dan tidak. Perbedaan ini dapat disebabkan oleh nilainilai yang hidup dalam suatu negara baik yang berkaitan dengan agama, filosofis, sosial, ekonomi dan faktor lainnya.20 Sehingga ukuran sesuatu hal sebagai pelanggaran etika bisnis atau tidak bisa berbeda-beda di tiap negara. Sederhananya, ketika terdapat suatu negara yang hukum, ekonomi dan pembangunannya lebih berkembang dari negara lain maka negara tersebut dapat saja memiliki ukuran etika yang lebih tinggi dari negara lain, untuk itu tiap negara perlu menetapkan standar yang dapat menjadi “jalan tengah". Jika ini dapat dilakukan maka amanat Article 192, Article 194, Article 207 dan Article 212 UNCLOS dapat dipenuhi oleh negara-negara.

Tantangan lain yang perlu diperhatikan adalah ketika etika bisnis khususnya dalam bidang kelautan mengharapkan negara yang tidak memiliki laut untuk taat. Hal ini menjadi suatu tantangan oleh karena dunia bisnis tentunya akan melihat keuntungan dari suatu ketaatan. Negara yang tidak memilki laut tentunya memiliki kepentingan yang lebih rendah terhadap etika bisnis kelauatan dibandingkan negara dengan kepentingan yang besar akan laut seperti Indonesia. Sehingga mengharmonisasikan etika bisnis tersebut terhadap negara yang demikian akan memiliki kesulitan tersendiri.

Lebih lanjut faktor lain yang perlu diperhatikan adalah terkait apakah suatu negara memiliki perhatian besar terhadap bisnis di bidang kelautan atau tidak. Hal ini

20 Bert Scholtens and Lammertjan Dam, “Cultural Values and International Differences in Business Ethics", Journal of Bussiness Ethic Vol 75, (2007): 273. 
tentunya akan berdampak pada perkembangan pelaku usaha di bidang kelautan. Ketika negara memberikan perhatian khusus dengan kebijakan-kebijakan khusus yang memperhatikan pelaku usaha terkait maka pelaku usaha baik perorangan maupun perusahaan akan lebih terhubung dengan negara. Keterhubungan ini akan membawa pada komunikasi yang baik antara pelaku usaha dengan negara. Ketika hubungan baik ini terjalin maka dengan mudah bagi suatu negara untuk menurunkan etika bisnis di level negara ke level pelaku usaha melalui suatu kode etik pelaku usaha kelautan. Dengan demikian etika bisnis yang telah dibentuk akan mampu menjalankan perannya dalam mengubah perilaku si pelaku usaha dan perilaku pelaku usaha akan membawa perubahan pada dunia. ${ }^{21}$ Perubahan ini tentunya akan membawa pada tata Kelola kelautan yang lebih baik antar negara.

Tatangan berikutnya yang sulit untuk diabaikan adalah kondisi lingkungan yang terus mengalami degradasi. Populasi yang terus bertambah secara langsung akan berdampaknya tingkat konsumsi terhadap apa yang disediakan oleh lingkungan. Populasi dunia sedang berkembang sekitar 1,5 persen setiap tahun, dan secara kasar bertambah 90 juta orang di dunia ini setiap tahunnya. ${ }^{22}$ Jumlah penduduk yang besar ini tentunya akan mendorong industri untuk memproduksi sebanyak mungkin dan sayangnya upaya pemenuhan dengan cara eksploitasi sumnber daya alam akan mengancam keseimbangan ekosistem. Sehingga tidak aneh jika kegiatan overfishing terus terjadi di hampir seluruh belahan dunia. ${ }^{23}$ Kegiatan overfishing ini biasanya berupa penangkapan ikan secara dini atau saat ikan belum bertumbuh, penangkapan ikan induk pemijah yang tidak terkontrol dan penangkapan secara berlebihan. ${ }^{24} \mathrm{Hal}$ ini juga diperparah dengan cara-cara penangkapan ikan yang tidak sesuai etika seperti penggunaan bom dan racun.

Kegiatan overfishing yang disampaikan diatas jika terus dibiarkan sebagaimana eksploitasi alam lainnya, akan berdampak pada punahnya suatu jenis flora maupun fauna. Dengan kata lain akan membawa pada the loss of biodiversity. Peristiwa ini tentunya akan memburuk oleh karena terganggunya rantai makanan di lingkungan. Belum lagi jika dihubungkan pada tantangan selanjutnya yakni

21 Emad Ali kasasbeh, et.al, "The Impact of Business Ethic in the Competitive Advantage (in the Cellular Comunication Between Operatiin in Jordan”, European Scientific Journal Edisi 10, No. 10, (2014): 270.

22 Mohammad Kemal Dermawan, "Perilaku Merusak Lingkungan Hidup: Perspektif Individu, Organisasi dan Institusional", Jurnal Legislasi Vol 6, No. 1, (2009): 78.

23 Indonesia termasuk dalam negara yang kerap mengalami overfishing. Kementerian Menteri Kelautan dan mencatat bahwa penangkapan ikan berlebihan ini terjadi karena industri perikanan yang tidak bekerja secara maksimal. Salah satu spesies ikan yang menjadi sorotan adalah Tuna. Untuk itu secara khusus pemerintah telah mengeluarkan Perpres No.9 Tahun 20075 Maret 2007 tentang Pengesahan Agreement for the Establishment of the Indian Ocean Tuna Commission (Persetujuan Tentang Pembentukan Komisi Tuna Samudera Hindia). Aturan ini diharapkan dapat mengatasi permasalah overfishing di Indonesia.

24 Suherman Banon Atmaja, et.al, "Overfishing Pada Perikanan Pukat Cincin Semi Industri di Laut Jawa dan Implikasi Pengelolaanya”, Jurnal Kebijakan Perikanan Vol. 3, No. 1, (2011): 53. 
perubahan iklim. Sebagaimana kita ketahui bahwa perubahan iklim juga berdampak pada punahnya beberapa spesies di alam. Tercatat, beberapa spesies di alam kesulitan beradaptasi terhadap perubahan iklim. ${ }^{25}$

Tantangan lain juga berkenaan dengan menodorng cara-cara diplomatis dalam penyelesaian sengketa laut. Konflik Laut China Selatan yang terus terjadi semakin menunjukan seberapa pentingnya laut bagi beberapa negara. Beberapa negara seperti China, Taiwan, Filipina, Vietnam, Malaysia dan Brunei menggunakan dalil yang berbedabeda untuk mengklaim laut tersebut. Bahkan proses klaim ini melibatkan negara-negara lain seperti Amerika Serikat dan Australia terlibat didalamnya meskipun tidak secara langsung memiliki kepentingan dengan laut tersebut. Namun karena hubungan baik dengan salah satu negara yang mengklaim maka keterlibatan itu pun tetap muncul. Kasus ini menunjukan bahwa bukan tidak mungkin akan ada kasus serupa seperti klaim Sipadan dan Ligitan dan Pulau Batuh Puteh yang akan terjadi di Asia Tenggara.

Persoalan tata laut ini semakin sulit diselesaikan oleh karena sengketa bukan hanya berkaitan dengan sumber daya alam di laut namun juga yang berkaitan dengan klaim maritim terkait kebebasan navigasi. Hal ini penting karena akan berdampak pada rute pengiriman dalam proses perdagangan internasional oleh negara-negara.
Selain itu, tumpang tindih dalam penegakan hukum juga menjadi tantangan tersendiri. Sinergi yang belum terbanung mengakibatkan keterpaduan antar sektor perikanan, industri maritim, jasa kelautan, transportasi laut, pariwisata bahari, pertambangan dan energi, bioteknologi, dan bangunan kelautan lainnya masih bermasalah hingga saat ini. ${ }^{26}$

Tantangan terakhir yang tidak kalah penting adalah sinergi tata Kelola laut dengan teknologi. Penggunaan teknologi yang diharapkan mampu mempermudah penataan laut ternyata memiliki tantangan tersendiri. Hal ini dikarenakan terdapat negara yang menggunakan teknologi bukan untuk kepentingan laut tapi kepentingan individu atau perorangan agar mempermudah proses eksplorasi dan eksploitasi laut. Penggunaan Unmanned Underwater Vehiche (UUV) atau kapal selam tanpa awak ternyata membawa pada isu hukum. Hal ini dikarenakan ketika UNCLOS dibuat, tipe teknologi seperti ini belum terpikirkan sehingga belum ada aturan yang komprehensif mengatur. ${ }^{27}$

\section{Kontribusi Hukum Internasional dalam Membentuk Etika Bisnis di Bidang Kelautan Indonesia}

Hukum internasional memang tidak serta merta menjamin adanya tata kelola yang baik (good governance), tapi harus diakui setidaknya hukum internasional dapat

$25 \mathrm{Ce}^{\prime}$ line Bellard, et.al, "Impact of Climate Change on the Future of Biodiversity", Ecology Letters, (2012) 15: 367-368.

26 Tridoyo Kusumastanto, Op. Cit, hlm. 5.

27 Aristyo Darmawan \& Jeremia Prasetya, "Law of the Sea not ready for modern technology?", The ASEAN Post, 13 November 2020, accessed at https://theaseanpost.com/article/law-sea-not-ready-modern-technology. 
berkontribusi dalam menyediakan suatu dasar dalam membentuk manajemen yang bertanggung jawab dan efektif bagi individu negara. ${ }^{28}$ Sebagaicontoh the Intergovernmental Oceanographic Commission (IOC) berhasil mempromosikan metode investigasi ilmiah kelautan dan the International Maritime Organization (IMO) menghasilkan panduan dalam bisnis pengangkutan dan bagaimana menghadapi polusi dari setiap aktivitas kelautan. ${ }^{29}$ Panduan tersebut telah diikuti oleh banyak negara dan menjadi standar etika yang diakui. ${ }^{30}$

Hukum internasional meskipun berada di level hubungan antara negara, tetap mampu menjadi alat atau saran membangun masyarakat, termasuk etika bisnis dan kelautan bagi masyarakat. Hal ini tidak terlepas dari pandangan Mochtar Kusumaatmadja yang mengemukan bahwa hukum itu bersifat memelihara dan mempertahankan yang sudah tercapai. ${ }^{31}$ Jadi ketika lingkungan dianggap menjadi bagian dari hidup masyarakat dan bahwa hak dari generasi yang akan datang adalah sesuatu yang penting maka penggunaan hukum internasional sebagai alat penyebarluasan etika bisnis kelautan menjadi relevan dan penting untuk dilakukan.
Hukum internasional melalui organisasi internasional juga terus berupaya mempromosikan upaya tata Kelola laut yang lebih baik. Uni Eropa misalnya, telah menunjukan komitmen akan tata kelolal laut. Melalui kolaborasi antara negara anggota guna melindungi dan memulihkan ekosistem laut dengan menginisasi "blue infrastructure" dan menyiapkan upaya mitigasi atas pemanasan laut yang merupakan dampak dari perubahan iklim. ${ }^{32}$ Legislasi di level Uni eropa dibentuk dan diselaraskan dengan legislasi di level internasional dengan merujuk pada perjanjian internasional dan organisasi internasional terkait serta Sustainable Development Goals yang sudah disepakati bersama oleh negaranegara. Komitmen ini diharapkan dapat dilaksanakan oleh negara-negara anggota.

Kerjasama maritim serupa juga sedang diupayakan terus menerus di ASEAN. Hal ini penting karena secara historis negara anggota ASEAN cukup sering terlibat sengketa laut. Melalui ASEAN Regional Forum (ARF), negara-negara anggota kerap mengangkat isu di ASEAN salah satunya adalah terkait ketahanan dan pertahanan dan persoalan Laut China Selatan. Isu-isu tersebut juga diselaraskan dengan pelaksanaan kesepakatan

28 Grip K., "International marine environmental governance: A review", Ambio 46 (4), (2017) hlm. 420-421.

$29 \mathrm{Ibid}, \mathrm{hlm} .418$.

30 Melalui hukum Internasional, etika bisnis dalam Rotary International yang berisi jutaan anggota yang merupakan pelaku bisnis berkembang. Salah satu pedoman etika bisnis yang dikeluarkan dan diikuti adalah the 4-Way Test yang cukup dikenal di banyak negara. Lihat, L. Soproni, "Ethics in international business", Annals of the University of Oradea - International Relations and European Studies Vol. 1, (2009): 5.

31 Mochtar Kusumaatmadja, Konsep-Konsep Hukum Dalam Pembangunan (Kumpulan Karya Tulis) (Bandung: Alumni, 2002), hlm. 14

32 Executive Summary, “Mitigating Climate Change Impacts on Food Security from The Ocean", (June 2019): 3-4. 
di level internasional seperti International Convention for the Safety of Life at Sea (SOLAS), 1972 International Regulations for Prevention of Collisions at Sea (COLREGs), dan the Code for Unplanned Encounters at Sea (CUES).

Harus diakui juga bahwa pelaku bisnis di bidang kelautan dapat juga diisi oleh perorangan atua korporasi. Diantara pelaku bisnis tadi, ada yang berafiliasi dengan negara (jika sahamnya dimiliki negara) dan yang tidak. Namun demikian, sebagai suatu subjek hukum, maka pelaku bisnis akan tunduk pada hukum negara di tempat dimana kegiatan berusaha berada dan hukum negara dimana pelaku usaha berpusat atau berdiri. Dengan demikian, hubungan internasional dan politik luar negeri dibutuhkan dalam hal penerapan hukum yang berpotensi lintas batas.

Hukum internasional khususnya hukum lingkungan mengatur aspek-aspek penting dalam aktivitas bisnis. Kegiatan-kegiatan seperti inovasi, pengambilan bahan mentah dari alam, produksi, distribusi, pemasaran, pengangkutan dan pembuangan limbah industri tidak lepas dari aturan hukum. ${ }^{33}$ Berdasarkan prinsip-prinsip hukum internasional, negara-negara diminta untuk menghindari adanya penggunaan wilayah teritorialnya yang dapat mengancam atau merugikan negara lain. ${ }^{34}$ Dengan demikian negara-negara wajib membuat suata etika agar pelaku usaha tidak berkontribusi dalam merusak lingkungan.

Salah satu etika yang diterima secara mayoritas oleh masyarakat baik di tingkat internasionalmaupunnasionaladalahtanggung jawab (responsibility). Di dalam konteks yang lebih luas etika ini bertransformasi menjadi tanggung jawab negara (state responsibility). Etika ini juga diejawantahkan oleh pelaku bisnis khususnya korporasi menjadi tanggung jawab sosial perusahaan (social corporate responsibility/CSR) selain adanya kode etik di level perusahaan yang diterapkan bagi pegawai. ${ }^{35}$ Dalam model CSR yang diperkenalkan Carrol, posisi tanggung jawab etik bahkan lebih tinggi dibandungkan tanggung jawab hukum. Lebih daripada mematuhi hukum, pegawai-pegawai dari suatu korporasi dituntut untuk memiliki kewajiban etik dalam melakukan apa yang benar dan adil agar tidak merugikan pihak manapun.36 Untuk itu CSR tidak boleh hanya menjadi elemen tambahan dalam kebijakan suatu korporasi tetapi juga harus diintegrasikan ke dalam strategi penataan korporasi. ${ }^{37}$ Ini berarti bahwa CSR harus menjadi budaya hukum bagi

33 David. M. Ong, "the Impact of Environmental Law on Corporate Governance: International and comparative perspective”, EJIL Vol. 12, No. 4, (2001): 685-686.

34 Max Valverde Soto, “General Principle of International Environmental Law”, ILSA Journal of Int'l \& Comparative Law Vol. 3, (1996): 195.

35 Mridula Goel dan Preeti E, "Ramanathan, Business Ethics and Corporate Social Responsibility - Is there a dividing line?", Procedia Economics and Finance Vol. 11, (2014): 50-51.

36 Anupam Krishna, et.al, "Business Ethics: A Sustainability Approach", Procedia - Social and Behavioral Sciences Vol. 25, (2011): 282.

37 Mridula Goel and Preeti E. Ramanathan, "Business Ethics and Corporate Social Responsibility - Is there a dividing line?", Procedia Economics and Finance 11, ( 2014 ): 51. 
tiap pegawai bukan hanya sekedar perintah hukum. Sebaliknya jika hanya menjadi kebijakan tambahan maka pelaksanaan CSR akan terhambat apabila ongkos pelaksanaanya besar.

Etika bisnis di bidang kelautan karena berkaitan dengan laut tentunya tidak lepas dari lingkungan. Laut sebagai bagian dari lingkungan saat ini menghadapi persoalan yang cukup besar. Untuk itu etika dalam penggunaan laut haruslah didasarkan pada prinsip sustainability (keberlanjutan). Prinsip ini mendorong keseimbangan antara pemenuhunan kebutuhan generasi sekarang dan generasi mendatang. Setiap aktivitas bisnis khususnya yang berdampak pada laut harus memastikan bahwa generasi yang akan datang dapat menikmati apa yang dinikmati generasi sekarang baik dari segi kuantitas maupun kualitas sumber daya laut. ${ }^{38}$ Our Common Future yang kerap dijadikan sebagai slogan dari pembangunan berkelanjutan mengharuskan negara-negara melakukan perubahan dalam hal pemikiran, kebijakan, pengaturan dan implementasi. Jika dirumuskan ke dalam suatu etika bisnis maka prinsip keberlanjutan dapat berupa larangan penangkapan ikan secara berlebihan khususnya anak ikan yang masih dalam proses pertumbuhan. ${ }^{39}$ Tapi tentunya tidak terbatas pada sesuatu yang sifatnya larangan karena larangan hanya bagian dari upaya pencegahan, yang ditujukan untuk mencegah eksploitasi lingkungan secara masif. Pencegahan memiliki aspek yang lebih luas lagi sampai pada upaya diteksi dini atas kemungkinan terjelek dari penataan yang tidak baik.

Selain itu, etika dalam kelautan (ocean ethic) memungkinkan perlindungan lingkungan yang nyata (baik dari tataran legislatif atau sebaliknya). ${ }^{40}$ Etika bisnis kelautan juga dapat dimulai dari awal investasi dilakukan. Etika investasi atau socially responsible investment (SRI) mendorong para investor untuk memperhatikan lingukungan bukan hanya karena adanya financial reward (baik dalam bentuk insentif atau pengurangan pajak) melainkan karena adanya dorongan moral untuk berkontribusi bagi dunia. ${ }^{41}$ SRI ini sejak awal memang didesain untuk mendukung pembangunan berkelanjutan. Oleh karena itu sasarannya adalah pelaksanaan

38 Cotter, Brennan, "Ethical Problems with Plastic in the Ocean", Senior Theses and Capstone Projects Vol. 113, (2019): 14, dapat diakses di https://scholar.dominican.edu/senior-theses/113.

39 Indonesia beberapa kali membuat peraturan yang melarang penangkapan benih spesies di laut agar siklus pertumbuhan ikan tidak terganggu. Sebagai contoh adalah dikeluarkannya Peraturan Menteri Kelautan dan Perikanan Republik Indonesia Nomor 56 /Permen-KP/2016 tentang Larangan Penangkapan dan/atau Pengeluaran Lobster, Kepiting dan Rajungan dari Wilayah Negara Republik Indonesia. Meskipun demikian, hasil penelitian menunjukan bahwa implementasi kebijakan tersebut tidak berjalan efektif dikarenakan beberapa kendala. Lihat, Furqan, et.al, "Tingkat Pemahaman Nelayan terkait dengan Kebijakan Pelarangan Penangkapan Benih Lobster Panulirus spp. Di Pelabuhan Ratu”, ALBACORE Vol. I, No 3, (Oktober 2017): 299-303.

40 Peter J. Auster, "Developing an Ocean Ethic: Science, Utility, Aesthetics, Self-Interest, and Different Ways of Knowing”, Conservation Biology Vol. 23, No. 1, (2008): 234.

41 Richardson, Benjamin J. "Keeping Ethical Investment Ethical: Regulatory Issues for Investing for Sustainability." Journal of Business Ethics 87.4 (2009): 557-558. 
tanggung jawab dari sektor keungan terhadap masalah lingkungan terutama yang terdampak dari adanya aktivitas ekonomi yang diawali oleh investasi. SRI ini bahkan membahas juga mengenai tanggung jawab korporasi yang ditandai dengan munculnya doktrin fiduciary duty. ${ }^{42}$ Dengan demikian semakin terlihat bahwa etika bisnis yang diinginkan mengkoneksikan dari pimpinan (direksi atau komisaris) kepada bawahan.

Agar proses pembangunan etika berjalan lancar maka keterlibatan organisasi internasional terkait perlu ditingkatkan, seperti Organization for Economic Co-operation and Development (OECD) yang menaungi beberapa negara dan menjalin kerjasama dengan banyak negara bukan anggota. Peran Organisasi Internasional sejenis menjadi penting karena adanya standar dan pedoman yang biasanya dibuat oleh organisasi tersebut bagi negara dan perusahaan.

Etika berinvestasi ini nantinya terhubung pada etika ekologis (echological ethics). ${ }^{43}$ Dengan adanya etika ekologis maka kegiatan investasi tidak hanya melihat pada seberapa banyak keuntungan yang dihasilkan melainkan seberapa besar suatu kehidupan dihargai. Kehidupan dari setiap mahluk hidup di lingkungan perlu menjadi pertimbangan termasuk isu mengenai masyarakat adat (indigenous communities). ${ }^{44}$

Penghormatan negara kepada masyarakat adat merupakan bagian dari beretika dalam negara. Dengan demikian hak-hak tertentu dari masyarakat adat tetap perlu diperhatikan termasuk kearifan lokal dari masyarakat tersebut. ${ }^{45}$ Hukum internasional cukup berperan dalam mendorong penghormatan pada masyarakat hukum adat. Terdapat beberapa produk hukum internasional yang menyinggung perihal masyarakat adat seperti Deklarasi Hak Asasi Manusia, ILO Convention, the International Covenant on Civil and Political Rights (ICCPR) dan lain-lain. ${ }^{46}$ Kesepakatan-kesepakatan tersebut meskipun tidak mengikat sebagai kewajiban hukum namun terbukti akhirnya mendorong negara-negara untuk memberikan perlindungan pada masyarakat adat masingmasing termasuk Indonesia. ${ }^{47}$ Penundukan

42 Ibid.

43 Etika lingkungan adalah moralitas bahwa manusia harus beradaptasi dalam berinteraksi dengan lingkungan. Tujuannya adalah untuk menghindari kerusakan yang terjadi pasca interksi tersebut. Lihat, Alyson C. Flournoy, In Search of an Environmental Ethic, 28 Colum. J. Envtl. L. 63 (2003): 72, available at http://scholarship.law. ufl.edu/ facultypub/57

44 Benjamin J. Richardson, "Putting Ethics into Environmental Law: Fiduciary Duties for Ethical Investment", Osgoode Hall Law Journal Vol. 46, Number 2 (Article 2, Summer 2008): 262-263.

45 Dwi Yono dan Iwan Permadi, "Keadilan Sosial Masyarakat Adat dalam Pengelolaan Wilayah Pesisir", Seminar Nasional Hukum Volume 2 Nomor 1, (2016): 309-310.

46 Alessandro Fodella, "International Law and Diversity of Indigineous Peoples", Vermont Law Review Vol. 30 , (2006): 566-570.

47 Salah satu tradisi lokal di Indonesia adalah tradisi Bapongka yakni yakni tradisi menangkap ikan, dilakukan secara kolektif, berpindah-pindah, mengeliling selama sekitar dua bulan, dan kemudian baru kembali pada titik yang sama. Tradisi ini ditunjukkan dengan sangat menjaga lingkungan laut. Lihat, Yohanes Kristiawan Artanto, "Bapongka, Sistem Budaya Suku Bajo dalam Menjaga Kelestarian Sumber Daya Pesisir", Sabda Vol. 12, No.1, (Juni 2017): 1-3. 
negara terhadap kewajiban tersebut dipandang sebagai bagian dari kebiasaan internasional yang sarat akan moralitas dan etika bernegara. ${ }^{48}$ Dengan adanya etika penghormatan pada masyarakat adat ini, negara dan pelaku bisnis diharapkan mampu berkoordinasi terkait kegiatan usaha yang akan dikembangkan di sekitar laut. Kegiatan bisnis tadi tidak boleh mengenyampingkan nilai-nilai masyarakat yang sudah diwarisi turun temurun.

Tata Kelola laut juga tentunya harus sampai pada tataran implementasi melalui penegakan hukum atas pelanggaran dan perusakan laut. Setiap bentuk perusakan laut sudah pasti melanggar etika bisnis baik etika yang berkaitan langsung dengan praktik bisnis maupun yang berhubungan dengan etika lingkungan.

Oleh karena tindak kejahatan di laut (sebagai contoh IUU) sangat kompleks maka sistem penegakan hukum yang bersifat global dan komprehensif dibutuhkan. Meskipun banyak upaya untuk menindak IUU dilakukan di level internasional namun pemerintah suatu negara (Indoensia) perlu menginisasi di level nasional. Hal ini dapat dilakukan melalui pengaturan di wilayah pesisir dan Pelabuhan, ratifikasi dan harmonisasi perjanjian internasional. ${ }^{49}$ Selain itu IUU ini biasanya berhubungan juga dengan kejahatan lain seperti narkotika dan perdagangan manusia.
Ditambah lagi jika yang berhubungan dengan pencemaran laut seperti tumpahan minyak (oil spill) yang jelas akan merusak lingkungan dan berdampak pada kehidupan masyarakat di wilayah pesisir.

Untuk itu, penegakan hukum juga hendaknya melibatkan kerjasama antara negara, antar Lembaga pemerintahan dan penegak hukum terkait. Tumpang tindih kewenangan dari penegak hukum sudah harus diselesaikan. Regulasi yang dikeluarkan pun hendaknya komprehensi sebagai bagian dari penataan laut yang memuat standar-standar dan pedoman berupa etika bisnis yang terdiri dari etika berinvestasi, etika menjankan bisnis, etika lingkungan dan etika penegakan hukum. Jangan sampai penegakan hukum yang dilakukan justru bertentangan dengan etika dan aturan hukum.

\section{Simpulan}

Hukum intenasional sejauh ini telah sukses mendorong negara-negara untuk menemukan nilai bermasyarakat yang dapat dijadikan sebagai standar hidup warga negaranya. Standar tersebut dapat berupa etika-etika bagi setiap entitas termasuk pelaku usaha baik perorangan maupun korporasi. Etika tersebut kemudian menjelma menjadi etika bisnis yang dianggap bagian penting dalam menata kelautan di Indonesia guna

48 James S. Phillips, "The rights of indigenous peoples under international law”, Global Bioethics Vol. 26, No. 2, (2015): 120 .

49 S. Widjaja, T. Long, H. Wirajuda, et al, Illegal, Unreported and Unregulated Fishing and Associated Drivers. (Washington, DC: World Resources Institute, 2019), hlm. 5. Dapat diakses di www.oceanpanel.org/iuu-fishingand-associated-drivers. 
mewujudkan tata kelola kelautan yang baik (good ocean governance). Meskipun hukum internasional dianggap bekerja dalam tataran antara negara namun pengejawantahannya dapat dilakukan di tingkat nasional melalui suatu perumusan code of ethic dalam berbisnis yang kemudian bekerja di level yang lebih kecil yakni etika bagi pegawai korporasi. Etika-etika seperti bertanggung jawab (responsibility), keberlanjutan (sustainability) dan penghormatan terhadap masyarakat adat adalah sedikit dari beberapa etika lainnya yang disebarluaskan oleh hukum internasional kepada setiap individu negara. Kemauan negara untuk mematuhi etika tersebut pun lahir dari rasa solidaritas antara negara yang merupakan aspek lain dari hukum internasional. Oleh karena sejak awal tidak ada lembaga legislatif, eksekutif dan yudikatif, maka upaya mengikat negara dilakukan melalui suatu etika bernegara. Suatu negara menganggap dirinya tidak etis jika tidak mengelola laut dengan baik ketika negara tersebut mengharapkan negara lain untuk beretika. Dengan kata lain, negara membentuk etika bisnis kelautan dengan harapan negara lain pun melakukan hal yang sama. Selain itu, peran hukum internasional melalui organisasi internasional semakin memperkuat upaya penataan laut dan pembentukan etika bisnis. Organisasi internasional dinilai mampu mewadahi kepentingan dan kebutuhan serta forum diskusi dan diplomasi antar negara. Organisasi internasional juga dapat dan telah mengeluarkan standar dan pedoman bagi tiap negara anggota dan oleh karena negara telah menyatakan komitmennya pada organisasi internasional maka akan lebih mudah menuntut ketaatan terhadap produk standar dan pedoman tersebut.

\section{DAFTAR PUSTAKA}

\section{Buku}

Harrison, James. Evolution of the law of the sea: developments in law-making in the wake of the 1982 Law of the Sea Convention. Edinburgh: School of Law, University of Edinburgh, 2007.

Ibrahim, Johnny. Teori dan Metodologi Penelitian Hukum Normatif. Malang: Bayumedia Publishing, 2006.

Kusumastanto, Tridoyo. Kebijakan Tata Kelola Kelautan Indonesia (Indonesia Ocean Governance Policy). Bogor:
Pusat Kajian Sumber Daya Pesisir dan Lautan, 2010.

Kusumaatmadja, Mochtar. Konsep-Konsep Hukum Dalam Pembangunan (Kumpulan Karya Tulis) Bandung: Alumni, 2002

Mulyaningsih dan Tinneke Hermina. Etika Bisnis. Bandung: Kimfa Mandiri, 2017. Myjer, Eric. The Principle of Approximate Treaty Application in evolving principles of International Law. Leiden: Brill-Nijhoff, 2011. 
Stanwick, Peter Allen dan Sarah D Stanwick. Understanding Business Ethics, Third Edition. New York: SAGE Publication, 2015.

Shidarta. "Dampak Pergeseran Etika dalam Kehidupan Berbangsa", dalam Komisi Yudisial, Etika dan Budaya Hukum dalam Peradilan, Cetakan Pertama. Jakarta: SekJen Komisi Yudisial RI, 2017.

S. Widjaja, T. Long, H. Wirajuda, et al, Illegal, Unreported and Unregulated Fishing and Associated Drivers. Washington, DC: World Resources Institute, 2019.

\section{Jurnal}

Adda, Godfrey, et.al. "Business Ethics and Corporate Social Responsibility for Business Success and Growth". European Journal of Business and Innovation Research Vol.4, No.6, (December 2016).

Artanto, Yohanes Kristiawan. "Bapongka, Sistem Budaya Suku Bajo dalam Menjaga Kelestarian Sumber Daya Pesisir". Sabda Vol. 12, No. 1, (Juni 2017).

Auster, Peter J. "Developing an Ocean Ethic: Science, Utility, Aesthetics, Self-Interest, and Different Ways of Knowing”. Conservation Biology Vol. 23, No. 1. (2008).

Bellard, Ce' line et.al, "Impact of Climate Change on the Future of Biodiversity". Ecology Letters, (2012): 15.
Boldizar, Alexander dan Outi Korhonen. "Ethics, Morals and International Law". European Journal of International Law Vol. 10, No.2. (1999).

Cotter, Brennan. "Ethical Problems with Plastic in the Ocean". Senior Theses and Capstone Projects Vol. 113, (2019).

Dermawan, Mohammad Kemal. "Perilaku Merusak Lingkungan Hidup: Perspektif Individu, Organisasi dan Institusional”. Jurnal Legislasi Vol 6, No. 1, (2009).

Flournoy, Alyson C. "In Search of an Environmental Ethic". 28 Colum. J. Envtl. L. 63 (2003).

Fodella, Alessandro. "International Law and Diversity of Indigineous Peoples". Vermont Law Review Vol. 30, (2006).

Furqan, et.al. "Tingkat Pemahaman Nelayan terkait dengan Kebijakan Pelarangan Penangkapan Benih Lobster Panulirus spp. Di Pelabuhan Ratu”. ALBACORE Vol. I, No 3, (Oktober 2017).

Goel, Mridula dan Preeti E. "Ramanathan, Business Ethics and Corporate Social Responsibility - Is there a dividing line?". Procedia Economics and Finance Vol. 11, (2014).

$\mathrm{K}$, Grip. "International marine environmental governance: A review”. Ambio 46 (4), (2017).

Kadar, A., "Pengelolaan Kemaritiman Menuju Indonesia sebagai Poros Maritim Dunia”. JURNAL KEAMANAN NASIONAL Vol. I, No. 3, (2015). 
Kasasbeh, Emad Ali et.al, "The Impact of Business Ethic in the Competitive Advantage (in the Cellular Comunication Between Operatiin in Jordan”. European Scientific Journal Edisi 10, No. 10, (2014).

Krishna, Anupam, et.al. "Business Ethics: A Sustainability Approach". Procedia Social and Behavioral Sciences Vol. 25 , (2011).

Mukuki, Allan Munyao. "The Normative Irrelevence of Austin's Command Theory, in International Law". MIMBAR HUKUM Vol. 28, No. 3, (2018).

Ong, David. M. “The Impact of Environmental Law on Corporate Governance: International and comparative perspective". EJIL Vol. 12, No. 4, (2001).

Phillips, James S. "The rights of indigenous peoples under international law". Global Bioethics Vol. 26, No. 2, (2015).

Posner, Eric A. "Do States Have a Moral Obligation to Obey International Law?". Stanford Law Review Volume 55, (2003).

Purwaka, Tommy Hendra. "Tinjauan Hukum Laut terhadap Wilayah Negara Kesatuan Republik Indonesia”. Mimbar Hukum Vol. 26, No. 3, (Oktober 2014).

Pyć, D. "Global Ocean Governance". The International Journal on Marine Navigation and Safety of Sea Transportation Vol. 10, Number 1, (March 2016).
Quirk, Genevieve dan Quentin A. Hanich, "Ocean Diplomacy: The Pacific Island Countries' Campaign to the UN for an Ocean Sustainable Development Goal". Asia-pacific journal of ocean law and policy Vol. 1, No. 1, (2016).

Richardson, Benjamin J. "Putting Ethics into Environmental Law: Fiduciary Duties for Ethical Investment". Osgoode Hall Law Journal Vol. 46, Number 2, (Article 2, Summer 2008).

Scholtens, Bert and Lammertjan Dam. "Cultural Values and International Differences in Business Ethics". Journal of Bussiness Ethic Vol 75, (2007).

Soto, Max Valverde. "General Principle of International Environmental Law". ILSA Journal of Int'l \& Comparative Law Vol. 3, (1996).

Soproni, L. "Ethics in international business". Annals of the University of OradeaInternational Relations and European Studies Vol. 1, (2009).

Suherman Banon Atmaja, et.al. "Overfishing Pada Perikanan Pukat Cincin Semi Industri di Laut Jawa dan Implikasi Pengelolaanya". Jurnal Kebijakan Perikanan Vol. 3, No. 1, (2011).

Yono, Dwi dan Iwan Permadi. "Keadilan Sosial Masyarakat Adat dalam Pengelolaan Wilayah Pesisir". Seminar Nasional Hukum Vol. 2, No. 1, (2016). 


\section{Internet}

Darmawan, Aristyo \& Jeremia Prasetya. "Law of the Sea not ready for modern technology?", The ASEAN Post, 13 November 2020. https://theaseanpost. com/article/law-sea-not-ready-moderntechnology.
Tjiptohandono, Dwi Aryo dan Indarwati Aminuddin. "WWF: Kondisi Kerusakan Laut Bisa Diperbaiki”. https://www. wwf.or.id/?41882/WWF-KondisiKerusakan-Laut-Bisa-Diperbaiki. 